\title{
ETHNIC RELATIONS IN MULTI-ETHNIC MALAYSIA
}

\author{
Naureen Nazar Soomro* \\ Aslam Pervez Memon ${ }^{* *}$
}

\begin{abstract}
The Malaysian society, one of the successful and managed multi-ethnic societies, is replete of imbalances and there still underlie the racial and ethnic disproportions in geographical dwellings, educational and professional fields, and economic and political roles. The modern racial relation in Malaysia is the legacy of pre-colonial and colonial period of history dating back to fifteenth and sixteenth centuries. The unstable demographic balance, the unrestricted immigration policy or the policy of divide and rule by the colonial masters contributed besides other reasons toward the troubled relations between ethnic communities of Malaysia- Malays, Chinese, Indians, and others. But the way the respective Malaysian governments have managed such sour relationship in their socio-economic and political spheres is the lesson that all multiethnic states can learn from.
\end{abstract}

Keywords: Malaysian multi-ethnic societies, pre-colonial and colonial period, Orang Asli

\section{Introduction}

Secession in previous centuries was considered near to impossible option for ethnic groups demanding it. But the secession of Soviet Union, the break-up of former Yugoslavia, the separation of Eritrea from Ethiopia has proved it wrong. The redrawing of boundaries, although solves the problem of multiethnic societies but only for the time being (Sisk, 1996).

The countries with ethnic strife opt for conflict management techniques for several reasons: when the groups desire to handle their differences; when they are longing to resolve all their outstanding issues; when the groups aspire for a better future, free from fear of any threat. The adoption of ethnic conflict management techniques depend upon the nature of society and the conditions that require particular technique (Kymlicka \& $\mathrm{He}, 2005)$. The issue of concern in any society that hinders the development and peace requires an understanding of the conditions or challenges facing the society.

The Malaysian society, one of the successful and managed multi-ethnic societies, is replete of imbalances and there still underlie the racial and ethnic disproportions in geographical dwellings, educational and professional fields, and economic and political roles. The modern racial relation in Malaysia is the legacy of pre-colonial and colonial period of history dating back to fifteenth and sixteenth centuries. The unstable demographic balance, the unrestricted immigration policy or the policy of divide and

\footnotetext{
* Naureen Nazar Soomro, Assistant Professor, Area Study Centre: Far East \& Southeast Asia, University of Sindh, Jamshoro

${ }^{* *}$ Aslam Pervez Memon, Ph.D. Professor, Department of Political Science, University of Sindh, Jamshoro
} 
rule by the colonial masters contributed besides other reasons toward the troubled relations between ethnic communities of Malaysia- Malays, Chinese, Indians, and others (Hirschman, 1986). But the way the respective Malaysian governments have managed such sour relationship in their socio-economic and political spheres is worth studying but beyond the scope of this paper.

This paper, therefore, focuses on the formation of racial and ethnic relations and root causes of conflict among the ethnic groups in multi-ethnic and multi-racial Malaysian society and the means by which it manages its ethnic peaceful coexistence. The paper is organized as follows. Section 2 reviews the history of ethnic relations in Malaysia. Section 3 puts forward the divide and rule policy of British that created politically strong Malays and economically strong Chinese and Indian communities, the section also reviews the relations between these ethnic communities after independence and section 4 concludes.

\section{History of Ethnic Relations}

The earliest immigration of the Malays to the Malay Peninsula between 2500 and 1500 B.C. can be considered as the foundation for the demographical construction of Malay society. Although the immigrants Malays from Indonesian archipelago (Hirschman, 1986) regard themselves as the indigenous population, but the aborigines or Orang Asli namely, were the original inhabitants of the Malay Peninsula. Those were displaced by the immigrant Malays from coastal areas to the swamps, hills and interior forests (Hui, 1980).

The immigrant Malays and aboriginals had remained isolated and confined to the Malay Peninsula only until the creation of Malacca Sultanate in $14^{\text {th }}$ Century which paved the way for international trade and interaction with outer world. Traders from other parts of the world in general and from India, China and Middle Asia in particular started migrating towards this region because of its strategic location that was quite beneficial in terms of coastal fishing and rice cultivations. However, it was the European period that played a significant role in determining the nature of relations among the immigrants and the original dwellers. It was not until the European rule in the $16^{\text {th }}$ century (Hui, 1980) that this area saw the permanent settlers of Chinese and Indian heredity.

The Chinese and Indian traders had no intention of settling permanently or gaining political control but to exploit the trading routes to other parts of the world. It was purely commercially motivated. As compared to barter-like nature of Chinese and other non-European traders to Malay Peninsula, the Europeans were more of a competitive and capitalist ideology (Hui, 1980). The first Europeans who gained power of Malacca in 1511 were Portuguese which ruled until 1641when Dutch captured the area from them. The British took over the Malacca and Penang from Dutch in 1786 and retained it under the administration of East India Company. Singapore was however, handed over to British only in 1819 (Hack, 2001).

The relationship at that stage between Chinese and the Malacca rulers were that of traders and local rulers. There were no ethnic and racial conflicts before the European 
colonial period. Lim Mah Hui describes that European rulers were however inclined towards creating a "direct political rule" (Hui, 1980:133) over the natives in order to retain the monopoly in trades. Aihwa Ong asserts that Europeans "indirectly" ruled the native land, cultivation and populations of the Malay states through introduction of political and legal changes in governing policies (Ong, 1987:11). Whether direct or indirect, it is obvious that, the nature of relationship between the natives and immigrant populations definitely changed after the Europeans arrived in the region. The ideological difference of natives and immigrant population did not exist before that.

Not only the natives and immigrant differences appeared with the European rule, the urban and rural divide did also contribute to the multiethnic strife between the ethnic communities.

\section{Rural-Urban Divide}

Before going on further, it is necessary to give some accounts of rural Malayan society and Malays themselves. The tributary system prevailed in the villages of Malay Peninsula in the $19^{\text {th }}$ century. The hierarchy of the system consisted of Sultans or monarchs, with most of the concentration of wealth in their hands; followed by the middle men, living on taxes received from the trade on rivers and cultivation. At the bottom of the pyramid were the peasants or producers of the land living on wages paid by middle men for their labour (Ong, 1987).

By late nineteenth century, the potential of tin mining has been identified by the Malay rulers. By that time, most of the villages have been vacated by the inhabitants due to heavy extraction demands and increasing land laws. Previously there was no concept of privatisation of land, any peasant could use it for self subsistence produce but British introduced some land laws to guarantee private ownership of land which forced Malay peasants to move towards jungles and lightly populated settlements. It was in such a condition that British seized control of most of the land and by paying compensations convinced the Malay rulers to hand over the administrative control of collecting the revenue legally (Ong, 1987). With the expansion of the tin production and then rubber plantations, there grew the need of immigration of Chinese and Indians to work in tin and rubber industries. The peasants then would only work for rice ploughing, hunting and catching fish, and sometimes carry out low level trade by selling their surplus produce to the Chinese living in tin mining camps.

The rivalries among Malay chiefs and conflicts within Chinese groups disrupted the tin production, consequently giving reason to British intervention. The colonial expansion and accompanying immigrations were the causes behind the creation of plural society of Malaysia (Islam, 1989). The differences in British policies towards immigrant population on one side and the Malays on the other had founded the character of relations amongst the varying communities in modern time Malaysia. Before late nineteenth century the Chinese-Malay relations were less threatening, because of assimilating nature of Chinese community and tolerant that of Malays.

Both the communities experienced the conflict within their own clan rather than with other communities because all the communities were themselves a mix of many linguistic and cultural groups (Singh, 2001). Nevertheless, the distance and differences among the communities living in Malaya are the creation of British imposed policy of 
divide and rule. British adopted different approaches towards the immigrants and towards natives. The Chinese and Indian were brought in for various purposes ranging from conducting hinterland trade to intermediaries of middle men for their east-west trade to indentured labours for working in tin and rubber plantations. With the Malays, however, British policy was that of mutual accommodation with royal elite to gain their support and fortification and domestication of peasants to improve peasant agriculture (Ong, 1987). It was in this situation that the relations between immigrants and natives were kept very much confined to their own spheres and sometimes to the markets as buyers and sellers only.

With the introduction of the land registration system, two policies were adopted, first, the land previously not allowed to be sold and purchased was now subject to sale, lease, or mortgage, and second, the coexistence of plantation agriculture with peasant agriculture was allowed (Hui, 1980). The introduction of land and agriculture policies and then abrogation of the same placed an immense impact on the ethnic and class relations. The class and subsequently ethnic differences widened. These differences were very much apparent between the non-Malay planter class who had now achieved sufficient land and the Malay peasants because of the sale of their land and among Malays because of the gap between Malay peasants and the Malay landlords. The gap between Malay landlords and Malay peasants was mainly because of the strengthened economic position of the former and weakened that of the latter. However, the immigrants remained in urban areas where initially British have installed them which created a rural-urban divide along with native-immigrant split.

Table 1: Rural-Urban Ethnic Makeup in Malaysia

\begin{tabular}{|l|l|l|l|l|l|l|}
\hline \multicolumn{6}{|c|}{ Urbanization by ethnic group (as a percentage) in Peninsular Malaysia } \\
\hline & \multicolumn{2}{|c|}{1947} & \multicolumn{3}{c|}{1957} & \multicolumn{2}{c|}{1970} \\
\hline Ethnic group & Urban & Rural & Urban & Rural & Urban & Rural \\
\hline Malays & 7.3 & 92.7 & 11.2 & 88.8 & 14.9 & 85.1 \\
\hline Chinese & 31.1 & 68.9 & 44.7 & 55.3 & 47.4 & 52.6 \\
\hline Indians & 25.8 & 74.2 & 30.6 & 69.4 & 34.7 & 65.3 \\
\hline
\end{tabular}

Source: (Watson 1980: 150)

The above table clearly depicts the urban and rural divide of Malaysian society in which Chinese and Indians form the major portion of urban population whereas the Malays inhabit the rural areas. In short one can say that the multi-ethnic society of Malaysia is not only divided along the ethnic lines alone, but also on economic lines as well. Apparently the Malay Reservation Act for land was to protect the indigenous Malay right over their land but in fact it was policy of British to keep Malay community confined to agriculture sector to feed all other communities giving immigrant population upper hand in economic side. 


\section{Ethnicity in Political Development}

The indigenous Malays demanded to bring an end to the immigrations as they had apprehension of the domination of immigrant population. In early 1930s the Malays were only $44.7 \%$ of the total population and with slight difference Chinese stood at $39 \%$ of the federation (Hui, 1980:146). Due to these demands, Hui believes the Aliens Ordinance came into force for the purpose of restrictions on immigration process to prevent the country not only from the economic imbalances but from political unrest. By the late 1930s the immigration was ceased (Hui, 1980). The Chinese community resented this immigration control policies. The Indians raised their voice through Indian National Congress (Turnbull, 1974) which echoed that the Indians are not satisfied with their position in Malaya. The Chinese and Indians, who were then the permanently settled immigrants, demanded more and more rights of participation in the state affairs (Hui, 1980). There was no change in policy, however, until the time the Japanese invaded Malaya.

The Japanese take over from 1942 to 1945 had worsened the ethnic relations in the Malay Peninsula. The inter-communal conflicts were dormant in pre-war period (Second World War), but during the Japanese take over the communal antagonism had activated. The old enmity with China compelled Japanese to bring the Chinese community under its submission. Not only those who were pro-communist or pronationalists were executed, the community as a whole was labelled as un-cooperative. The resistances by Chinese guerrillas were battled by Japanese with the help of Indians and Malays as these two communities were believed to be supportive in resistance movement. In retaliation, the Chinese guerrillas attacked Malay villages, thus deteriorating the Chinese and Malay relations (Ratnam, 1965). It was visible from the circumstances at that time that there was a lack of unification between ethnic communities in Malaya.

After the end of Japanese invasion, British returned in 1946 with the proposal of Malayan Union. The provisions set in the proposal were: the abolition of the Sultan system; the granting of equal political and cultural rights to whole population; and granting of nationality and citizenship to all permanent residents (Horii, 1991). It wished for the creation of a modern state with equal participation of all its ethnic and racial groups. The idea was unacceptable to and opposed by the Malay community, because of fear of Sultan system abolition and consequently of the traditional Malay society. The Malay upper class strongly opposed the abolition of sultan system, and created the United Malays National Organization (UMNO) in response. The Malays managed to get their special privileges written in the constitution, in return to the granting of citizenship and permission of political participation to those groups who were economically better off than Malays - the Chinese and the Indians (Horii, 1991). 


\section{Ethnic Relations after Independence (1957-1969)}

The Peninsular Malaysia that is Western Malaysia achieved independence in 1957, whereas Sabah and Sarawak jointly called the Borneo states and Singapore achieved the same in 1963 and joined the Federation of Malaysia (Morley, 1999). However, Singapore left the union peacefully in 1965 due to political and economic competition between the two nations.

\section{Politics and Ethnicity}

Demographically, Malaysia comprises of majority of Malays- 63 percent of the population of Malaysia that are politically dominated whereas the minorities that dominate economic activities in Malaysia are Chinese about 25 percent (Tamam, 2009) and to some extent Indians. In 1860s the states of Penang, Malacca, Singapore, Perak, Selangor, Negeri Sembilan and Pahang came under the control of British and were renamed the Federated Malay States. The term Unfederated Malay States was assigned to the other states which were outside federated groupings of states. This broad British control remained until outbreak of Second World War when losing into hand of Japanese from 1942 to 1945 (Swee-Hock, 2007).

Federation of Malaya emerged as Malaysia when inclusion of Singapore, North Borneo (Sabah here after) and Sarawak took place in 1963 (Liu \& Lawrence et. al, 2002). Singapore was granted internal self government in 1959 and People's Action Party (PAP) under the leadership of Lee Kuan Yew gained control of it through democratic elections. He still sought complete independence through merger with federated states of Malaya (Liu \& Lawrence, et al., 2002). The Malaysian government was reluctant to include Singapore because the large number of Chinese in Singapore would gain enormous economic benefit from Malaysia and it would also make difficult for Malaysian government to reduce the economic inequalities between Malay and Chinese communities living in Malaya (Milne, 1963). Gordon Means (1976) believes that there was a fear of Singapore going communist which could overrun the whole of Malaya with the help of the communist powers and this threat compelled the Malayan federation to incorporate Singapore into the federation (Means, 1976). On the Singaporean side, on the issue of merger, there was a genuine fear in masses that the merger with Malayan federation would be possible only after many concessions from Singapore (Milne, 1967).

The reason behind the separation of Singapore from Malaysia in 1965 was the reluctance of Singapore government to adopt the centralized politics of Malaysian government that focused on the Malay and other indigenous community in Malaysia at the expense of Chinese population in Singapore (Jawan and Yusoff, 2009). Some of the major issues between the two states were: the political threat posed by the anti-Malaysia opposition parties; the formulation of economic policies for a common market; the extension of federal authority and government services into Singapore and the Borneo states; and the creation of a pan-Malaysian party system (Means, 1976: 333). Somewhat similar reasons of Singapore-Malaysia frictions except few were given by Robert Young 
(1994) in his article explaining the peaceful secessions of Singapore-Malaysia, AustriaHungary and Norway-Sweden (Young, 1994).

Ethnic or racial differences emerged over the Malaysian policy of "Malay Malaysia" whereas PAP favoured a "Malaysian Malaysia" (Milne, 1966). The accession of Singapore brought about 80 percent Chinese population to the Federation which disturbed the demographical balance in Malaysian society (Young, 1994) where Malaysian and Chinese were in the proportion of 49.8 and 37.1 percent respectively (Federation of Malaya Yearbook, 1962).

The leaders of two other states of Sabah and Sarawak, Donald Stephen of United National Kadazan Organization in Sabah, and Datu Bandar Abang Haji Mustapha, President of the Party Negara in Sarawak at first were, to some extent, reluctant to join Malaysia as they considered it as a step towards colonising Borneo states. However, the political system of Malaysia that ensured the freedom of expression of voters of Malaysia and that they could have the power of approving and disapproving of government through ballot box was the reason on side of both Sabah and Sarawak that convinced them to join the federation (Abidin, 1964).

The political, economic, and cultural disparities have persisted in Malaysia since colonial era. Even after independence until 1970 the inequalities in major ethnic groups, Malays, Chinese and Indians have remained a conflict-ridden issue. The contests among the states of East and West Malaysia due to disparities in states have disturbed the functioning of federation from time to time. The following section deals with the issues of political, economic and other social imbalances in Malaysian society since independence until the violent racial riots of 1969.

\section{Economic Imbalances and Ethnicity}

After the British departure and the independence, the formula of counterbalancing the Malay political power with the Chinese and other immigrants' economic power did not work well after independence. The lack of interaction among ethnic groups widened the gap and grievances against one another's powers. The major event that complies with this argument is May 1969 racial riots that brought major shift in the country's political, social and economic life.

Government introduced various development programs for rural areas of Malaysia, like Rural Development Program (Abdullah, 1997), whereby a number of programs were carried out in rural areas to improve living conditions of peasantry. On urban side, government attempted to increase the ratio of Malay capitalist class that was very low as compared to other communities. The laissez-faire system that identifies low level of government interference in economic and business activities favoured already established businesses, further enhanced the business capabilities of the non-Malay enterprises (Brennan, 1982). 
The Malay share of capital ownership in public limited companies until 1970s remained as low as 1.9 per cent against the 22.5 per cent of Chinese share and 86.7 per cent by foreign companies (Malaysia, 1971). However, It is clear from the statement in Second Malaysian Plan 1971-1975, which states that "despite the significant progress made in improving the economic well-being of the have-nots, the problem of economic imbalance remained" (Malaysia, 1971:18) and that "although rapid strides were made in development, the continued to face the problems of poverty, unemployment and economic imbalance, particularly among the racial groups" (Malaysia, 1979: 16).

The optimism of Malays shattered after these reports as they were expecting their proper place in their country after independence. But the persistent economic imbalances grew strong criticism of government policies. On the other hand, the Chinese, wary of political dominance of Malays, began to oppose government policies focused on Malays political and economic safeguard (Hashim, 1998). The unequal wealth distribution, the urban and rural divide, and economic imbalances among the ethnic groups, weakened the basis of consociational democracy because the socio-economic equality is one of the favourable factors for the consociational democratic government (Bogaards, 1998).

The demands for equal sharing of state's wealth were increasing. The result was 1969 race riots where the Alliance Party loses about 10 per cent of its votes as compared to 1964 elections (Ratnam and Milne, 1970). The riots on May 13 started when some Malay supporters attacked the victory parade of Chinese in the city of Kuala Lampur where migrated Malays from rural areas lived in poor conditions against the wealthy Chinese. The government was accused of being lenient towards Malay rioters, losing its faith among non-Malays (Drummond and Hawkins, 1970).

It shattered the image of coexistence that apparently persisted in Malaysian society and made clear that there lays some sensitive communal cleavage deep down the social order. The resultant of these riots was the New Economic Policy introduced by government in 1971 with the main purpose of lessening the gap between ethnic groups and between rich and poor.

Indian origin people living in Malaysia also feel marginalized, alleging native sociopolitical forces for keeping them excluded from the mainstream of national development in almost every walk of life. Lahiri (2008), points out that Malaysian Indians allege that they have faced severe economic discrimination as the result of the 1971 preferential policies. Those are discriminated against at the time of allotment of business licenses, the awarding of government scholarships, the appointments of teachers and lecturers, citizenship applications, allotment of lands and the like.

The New Economic Policy, nevertheless, has outlined the two major objectives which the Malaysian society has achieved to great extent: to reduce and eliminate poverty irrespective of race, and to restructure Malay society so as to correct economic imbalance and eliminate the identification of race with economic function (Hart, 1994). 


\section{Conclusion}

Unlike Portuguese and Dutch, the British colonial powers interacted much with the local community that altered the structure and culture of society. The divide and rule policy of British colonisers is apparent in present day Malaysian society, which divided the society along communal lines. On economic side, the unrestricted immigrations of Chinese and Indians at one point around 1930's outnumbered the Malay population (Hwang, 2003). Chinese and Indians arrived in Malaya as indentured labours to work in tin mines and rubber plantations and engage in other commercial businesses. The Malay peasants were kept confined to their traditional village environment, keeping majority of Malay on the unwaged subsistence agriculture (Hirschman, 1982). Thus by reinforcing an ethnic division in residence and economic activities or in other words by creating an economic dualism, the British colonisers kept Malay, Chinese and other immigrants isolated from each other. But the New Economic Policy introduced to address the root causes of interethnic tensions after the ethnic disturbances in 1969 has helped Malaysia restructure its society by eradicating poverty and by increasing Malays' share of the economy.

\section{References}

Abdullah, Firdaus Hj. (1997) Affirmative Action Policy in Malaysia: To Restructure Society, to Eradicate Poverty. Ethnic Studies Report, XV (2), pp. 189-221.

Abidin, Zainal Bin Abdul Wahid. (1964). Malaysia, Southeast Asia and World Politics. In: Gungwu, Wang (ed.) Malaysia: A Survey. London: Pall Mall Press, pp. 365-374.

Bogaards, Matthijs. (1998) The Favourable Factors for Consociational Democracy: A Review. European Journal of Political Research, 33 (4), pp. 475-496.

Brennan, Martin. (1982) Class, Politics and Race in Modern Malaysia. Journal of Contemporary Asia, 12 (2), pp. 182-215.

Drummond, Stuart and Hawkins, David. (1970) The Malaysian Elections of 1969: An Analysis of the Campaign and the Results. Asian Survey, 10 (4), pp. 320-355.

Federation of Malaya Official Year Book, 1962, Vol. 2. Kuala Lampur: Government Press.

Hack, Karl. (2001) Defence and Decolonisation in Southeast Asia: Britain, Malaya and Singapore 1941-1968. London: Curzon Press.

Hart, Gillian. (1994) The New Economic Policy and Redistribution in Malaysia: A Model for Post-Apartheid South Africa? Transformation, 23, pp. 44-57.

Hashim, Shieen Mardziah. (1998) Income Inequality and Poverty in Malaysia. Lanham, Md.: Rowman \& Littlefield.

Hirschman, Charles. (1982) Unemployment among Urban Youth in Peninsular Malaysia, 1970: A Multivariate Analysis of Individual and Structural Effects. Economic Development and Cultural Change, 30 (2), pp. 391-412. 
Hirschman, Charles. (1986) The Making of Race in Colonial Malaya: Political Economy and Racial Ideology. Sociological Forum, 1 (2), pp. 330-361.

Horii, Kenzo. (1991) Disintegration of the Colonial Economic Legacies and Social Restructuring in Malaysia. The Developing Economies, XXXIX (4), pp. 281-313.

Hui, Lim Mah. (1980) Ethnic and Class Relations in Malaysia. Journal of Contemporary Asia, 10 (1/2), pp. 130-154.

Hwang, In-Won. (2003) Personalized Politics: The Malay State under Mahathir. Singapore: Institute of Southeast Asian Studies.

Islam, Nazrul M. (1989). Pakistan and Malaysia: A Comparative Study in National Integration. New Delhi: Sterling Publishers.

Jawan, Jayum A. \& Yusoff, Muhammad Agus. The 2008 Malaysian General Elections: Implications for Ethnic Relations. World Civic Forum 2009. Kyung Hee University and United Nations Department of Economics and Social Affairs.

Kymlicka, Will \& He, Baogang. (2005) Multiculturalism in Asia. Oxford: Oxford University Press.

Lahiri, Dilip. (2008) Malaysian Indian Community: Victims of 'Bumiputera' Policy. ORF Issue Brief, No. 12. New Delhi: Observer Research Foundation.

Liu, James H. Lawrence, Belinda; Ward, Colleen and Abraham, Sheela. (2002) Social Representations of History in Malaysia and Singapore: on the Relationship between National and Ethnic Identity. Asian Journal of Social Psychology, 5 (1), pp. 3-20.

Malaysia, Government of. (1971) Second Malaysian Plan, 1971-1975. Kuala Lampur: Government Press.

Malaysia, Government of. (1979) Third Malaysian Plan, 1976-1980. Kuala Lampur: Government Press.

Means, Gordon P. (1976) Malaysian Politics. Second Edition. London: Hodder and Stoughton Limited.

Milne, R. S. (1963) Malaysia: A New Federation in Making. Asian Survey, 3 (2), pp. $76-$ 82 .

Milne, R. S. (1966) Singapore's Exit from Malaysia: the Consequences of Ambiguity. Asian Survey, 6 (3), pp. 175-184.

Milne, R. S. (1967) Government and Politics in Malaysia. Boston: Houghton Mifflin Company.

Morley, James William. (1999) Driven by Growth: Political Change in the Asia-Pacific Region. Armonk, NY: M.E. Sharpe.

Ong, Aihwa. (1987) Spirits of Resistance and Capitalist Discipline: Factory Women in Malaysia. Albany: State University of New York Press. 
Ratnam, K. J. (1965) Communalism and the Political Process in Malaya. Kuala Lampur: University of Malaya Press.

Ratnam, K.J. and Milne, R.S. (1970) The 1969 Parliamentary Election in West Malaysia. Pacific Affairs, 43 (2), pp. 203-226.

Singh, H. (2001) Ethnic Conflict in Malaysia Revisited. Commonwealth and Comparative Politics, 39 (1), pp. 42-65.

Sisk, Timothy D. (1996) Power Sharing and international mediation in ethnic conflicts. Washington, DC: United States Institute of Peace.

Swee-Hock, Saw. (2007) The Population of Malaysia. Singapore: Institute of Southeast Asian Studies.

Tamam, Ezhar. (2009). Contribution of Interethnic Contact on Interethnic Attitudes of Malay and Chinese-Malaysian University Students in Malaysia. European Journal of Social Sciences, 8 (1), pp. 51-61.

Turnbull, C.M. (1974) British Planning for Post-War Malaya. Journal of Southeast Asian Studies, 5 (2) The Centenary of British Intervention in Malaya, pp. 239-254.

Watson, J.K.P. (1980) Education and Cultural Pluralism in South East Asia, with Special Reference to Peninsular Malaysia. Comparative Education, 16 (2), pp. 139-158.

Young, Robert A. (1994). How do Peaceful Secessions Happen? Canadian Journal of Political Science, 27 (4), pp. 773-792. 